\title{
Cytochrome P450 enzymes inhibitor in the control of Digitaria insularis
}

\section{Inibidor das enzimas citocromo P450 no controle de Digitaria insularis}

\author{
Gledson Soares de Carvalho1 (iD), Jessica Ferreira Lourenço Leal² (D), Amanda dos Santos Souza² (D), \\ Francisco Freire de Oliveira Junior ${ }^{2}$, Ana Claudia Langaro ${ }^{1}$ (D) Camila Ferreira de Pinho ${ }^{*}$ (D)
}

1Universidade Federal Rural do Rio de Janeiro/UFRRJ, Instituto de Tecnologia, Seropédica, RJ, Brasil

2Universidade Federal Rural do Rio de Janeiro/UFRRJ, Instituto de Fitotecnia, Seropédica, RJ, Brasil

*Corresponding Author: camilafepi@ufrrj.br

Received in September 10, 2020 and approved in February 10, 2021

\begin{abstract}
Herbicide interactions can be synergic, additive, or antagonist when mixed in the spray tank. A good example is an association between 2,4-D and graminicides. One hypothesis is that 2,4-D contributes to increasing the Cytochrome P450 activity, which may be one of the causes of antagonism. This study aimed to investigate the use of CYP450 enzymes inhibitor associated with the herbicide mixtures 2,4-D and ACCase inhibitors in vivo on the control of Digitaria insularis. The experiment was performed using a randomized block design in a factorial scheme of $6 \times 2$ with four replications. Factor A consisted of untreated check, 2,4-D (1005 g a.e ha-1), clethodim (192 g a.i ha-1) and haloxyfop (62.4 $\mathrm{g}$ a.i ha-1 $)$, 2,4-D + clethodim (1005 g a.e ha-1 $192 \mathrm{~g}$ a.i ha-1), and 2,4-D + haloxyfop (1005 g a.e ha-1 $+62.4 \mathrm{~g}$ a.i ha-1 $)$. Factor $B$ represented the presence or absence of malathion $\left(1000 \mathrm{~g} \mathrm{ha}^{-1}\right)$ applied two hours before applying the herbicides. A physicochemical test was performed to verify the compatibility of the herbicides in the tank. Malathion application performed two hours before applying the herbicide mixtures (2,4-D and clethodim/haloxyfop) did not provide adequate control of sourgrass, suggesting that CYP450 enzymes inhibited by malathion are not involved in the antagonistic effect between 2,4-D and both graminicides in the management of sourgrass. The 2,4-D + haloxyfop in tank mix demonstrated less efficacy in controlling sourgrass than 2,4-D + clethodim, but both mixtures were incompatible in the tank mix, which may be associated with reduced efficacy in sourgrass management.
\end{abstract}

Index terms: Sourgrass; interaction; metabolization; malathion; 2,4-D; graminicides; CYP450.

\begin{abstract}
RESUMO
As interações entre herbicidas quando misturados na calda de pulverização podem ser sinérgicas, aditivas ou antagônicas. Um exemplo de antagonismo está na associação entre os herbicidas 2,4-D e graminicidas. Há a suspeita de que o 2,4-D contribui para o aumento da atividade do Citocromo P450, podendo ser esta uma das causas do antagonismo. O objetivo deste estudo foi investigar o uso do inibidor das enzimas CYP450 in vivo, associado às misturas de herbicidas 2,4-D e inibidores da ACCase, no controle de Digitaria insularis. O experimento foi realizado em delineamento de blocos casualizados em esquema fatorial $6 \times 2$ com quatro repetições, sendo o fator A os herbicidas: controle 2,4-D (1005 $\mathrm{g}$ a.e. ha-1); cletodim (192 $\mathrm{g}$ a.i ha-1 $)$ e haloxifope $(62,4 \mathrm{~g}$ a.i ha-1), 2,4-D+cletodim (1005 g a.e ha-1 +192 $\mathrm{g}$ a.i ha-1), 2,4-D+haloxifope (1005 $\mathrm{g}$ a.e ha-1 $+62.4 \mathrm{~g}$ a.i ha-1); e o fator B a presença ou não de malation (1000 $\mathrm{g}$ ha-1) aplicado duas horas antes dos herbicidas. Foi realizado um teste físico-químico para verificar a compatibilidade dos herbicidas no tanque. A aplicação do malation duas horas antes das misturas dos herbicidas 2,4-D+clethodim ou haloxyfop, não proporcionou controle satisfatório do capimamargoso, sugerindo que as enzimas CYP450 inibidas pelo malation não estão envolvidas no efeito antagônico observado. A mistura de 2,4-D+haloxyfop demonstrou menos eficácia no controle do capim-amargoso quando comparada com 2,4-D+clethodim, porém ambas foram incompatíveis na mistura em tanque, o que pode estar associado à eficácia reduzida no manejo do capim-amargoso.
\end{abstract}

Termos para indexação: Capim-amargoso; interação; metabolização; malation; 2,4-D; graminicidas; CYP450.

\section{INTRODUCTION}

Sourgrass (Digitaria insularis) is one of the most important weeds in Brazilian agriculture. It is a perennial grass, reaching up to $150 \mathrm{~cm}$ in height, with rhizomes and high seed production, facilitating dissemination
(Kissmann; Groth, 1997). Due to these characteristics, this species is aggressive, with a high competitive ability (Gazola et al., 2016). Two sourgrass plants per square meter can generate a loss of up to $375 \mathrm{~kg} \mathrm{ha}^{-1}$, while six plants per square meter can lead to losses up to $1300 \mathrm{~kg} \mathrm{ha}^{-1}$ of soybean (Gazziero et al., 2019). 
The phenological stage is very important in the management of sourgrass, and it is crucial to control in the initial stages. Studies indicate the complexity of controlling sourgrass once the rhizome is formed since it helps the regrowth; thus, impacting the management (Gemelli et al., 2012; Machado et al., 2008). Furthermore, the number of glyphosate-resistant (GR) sourgrass cases is increasing in Brazil (Takano et al., 2018), which makes acetyl-CoA carboxylase (ACCase) inhibitors, also known as graminicides, the main herbicide class to control this species (Barroso; Albrecht; Reis, 2014).

However, many different weed species, including monocots and dicots, impact weed management in a field production area. It is common to mix herbicides in the spray solution for treatment in such cases (Damalas, 2004; Hatzios; Penner, 1985).

The association of herbicides is usually carried out without the clear knowledge of the mixture's effect on the primary target, resulting in different interactions between herbicides (Arcaute; Soloneski; Larramendy, 2018; Calabrese, 1995). These interactions may be additive, synergistic, or antagonistic, with the response being equal, better, or worse than expected, respectively, compared to isolated herbicides (Colby, 1967).

Antagonism occurs when mixing two or more different herbicides, in which one reduces the effect of the other (Hatzios; Penner, 1985; Zhang et al., 2005). This effect is frequently observed between graminicides and latifolicides. Leal et al. (2020) reported the antagonism between 2,4-D and Haloxyfop for controlling $D$. insularis.

Among the studies frequently performed on antagonism, Cytochrome P450 (CYP450) enzyme activity has been significant. In this line, Han et al. (2013) reported that 2,4-D protected Lolium rigidum plants against diclofop-methyl by inducing the expression of CYP450 and other genes involved in the herbicide-metabolizing process.

Cytochrome P450, an enzyme complex found in the rough endoplasmic reticulum of plant cells (Werck-Reichhart; Hehn; Didierjean, 2000), metabolizes xenobiotic agents, including herbicides (Yu; Powles, 2014). The CYP450 enzymes inhibit the herbicides by the oxygenation, hydroxylation, or dealkylation of the herbicide into hydrophobic molecules, making them water-soluble and facilitating the degradation of plants (Werck-Reichhart; Hehn; Didierjean, 2000). There are many enzyme species in the CYP450 complex, such as monooxygenases, esterases, amidases, aryl acyl amidases, and nitrilase (Kreuz; Tommasini; Martinoia, 1996; Ogliari et al., 2014). Also, CYP450 includes many isoforms, and the number and type of these isoforms vary according to plant species (Werck-Reichhart; Hehn; Didierjean, 2000).

The base of the herbicide metabolism studies is the application of CYP450 enzyme inhibitors, such as aminobenzotriazole (ABT) and the organophosphate insecticides piperonyl-butoxide (PBO), but the most used is malathion (Yu; Powles, 2014). When CYP450 enzymes oxygenate malathion, a sulfur atom is released and attaches to the structure of the complex, which changes the molecular conformation; thus, leading to its inactivation (Dalazen et al., 2018).

Even though ACCase inhibitor herbicides control sourgrass (Barroso; Albrecht; Reis, 2014), when these herbicides are mixed with 2,4-D, a loss of efficacy is observed (Zobiole et al., 2016; Leal et al., 2020). In this case, the hypothesis is that the antagonism may occur due to the increment of CYP450 enzyme activity in the presence of 2,4-D. Consequently, the graminicides' herbicides are metabolized (Han et al., 2013; Hirose et al., 2007).

Therefore, this study aimed to investigate the use of CYP450 inhibitor in vivo, associated with the herbicide mixtures 2,4-D and ACCase inhibitors, to control Digitaria insularis.

\section{MATERIAL AND METHODS}

\section{Greenhouse experimental design}

The experiment was carried out in a greenhouse, and the $D$. insularis seeds were acquired by Agro Cosmos company, located in the city of Engenheiro Coelho, São Paulo, Brazil.

The sowing was done in September 2019, using polyethylene pots with $1000 \mathrm{~cm}^{3}$ of capacity. The soil was a mixture of clay and sand soil in a 1:1 ratio, and tests were conducted to determine this mixture. After the mixture, the soil's chemical characteristics were as follows: $\mathrm{pH}$ (water): 5.7 , organic matter: $0.78 \% \mathrm{P}_{2} \mathrm{O}_{5}$ and $\mathrm{K}_{2} \mathrm{O}$ with 42 and $46 \mathrm{mg} \mathrm{dm}^{-3}$, respectively. The soil was irrigated at field capacity and fertilized weekly with NPK (nitrogen, potassium, and phosphorus) 5-20-20 to improve plant growth.

The plants were thinned when it reached the 2-4 leaves stage, keeping one plant per pot until the flowering stage and then proceeding with the herbicide spraying.

The experiment was conducted using a randomized block design with a factorial scheme of $6 \times 2$ and four replications. Factor A included an untreated check and the herbicides 2,4-D (DMA $806^{\circledR}$ (SL) - $1005 \mathrm{~g}$ a.e ha ${ }^{-1}$ ), 
clethodim $\left(\right.$ Select $^{\circledR}$ (EC) - $192 \mathrm{~g}$ a.i ha $\left.{ }^{-1}\right)$, haloxyfopp-methyl (VerdictR ${ }^{\circledR}$ (EC) - $62.4 \mathrm{~g}$ a.i ha $^{-1}$ ), 2,4-D + clethodim and 2,4-D + haloxyfop-p-methyl. According to label recommendations, mineral oil $(0,5 \% \mathrm{v} / \mathrm{v})$ was added to the spray mix with ACCase inhibitor herbicides. Factor $\mathrm{B}$ consisted of the mixture with or without malathion $\left(1000 \mathrm{~g} \mathrm{ha}^{-1}\right)$, which was applied two hours before the herbicides (Dalazen et al., 2016; Dalazen et al., 2018).

The malathion and herbicides were sprayed using a $\mathrm{CO}_{2}$-pressurized backpack sprayer equipped with four TeeJet XR110020 flat-fan nozzles (TeeJet Technologies, Springfield, IL, USA), which delivered $150 \mathrm{~L} \mathrm{ha}^{-1}$ of spray solution at $280 \mathrm{kPa}$ and a ground speed of $4.53 \mathrm{~km} \mathrm{~h}^{-1}$ under environmental conditions of $22.6^{\circ} \mathrm{C}, 89.4 \%$ relative humidity, $2.5 \mathrm{~km} \mathrm{~h}^{-1}$ wind speed.

\section{Visual control}

Visual assessments of the weed control were performed at 14 and 35 days after applications (DAA) by assigning the visual symptoms a scale from $0-100 \%$. Here, $0 \%$ represents the absence of symptoms, and $100 \%$ represents the plant's death (Frans; Crowley, 1986).

\section{Chlorophyll $a$ fluorescence transient}

Chlorophyll $a$ fluorescence transient was measured in dark-adapted leaves using a HandyPEA fluorimeter (Plant Efficiency Analyzer, Hansatech Instruments Ltd, UK) at 14 and 35 DAA of the herbicides. The fully expanded first leaf was kept in the dark in specially provided clips for at least 20 min to conduct measurements in the middle third of the leaves during the morning period. Fluorescence data were analyzed according to Strasser, Tmilissi-Michael, and Srivastava (2004) and TsimilliMichael and Strasser (2008). The plotted fluorescence values were the average of eight measurements of each treatment.

\section{Dry mass}

The shoot of plants was collected at 35 DAA, separated in paper bags, and placed in an oven with forced air circulation at $60 \pm 5{ }^{\circ} \mathrm{C}$ until they reached a constant mass $(\sim 72 \mathrm{~h}$ ) to determine the shoot dry mass (SDM).

\section{Compatibility tests}

The physicochemical compatibility test in the spray solution was performed to verify the pesticides' behavior when mixed in the tank using the methodologies from NBR 13875:2014 of the Brazilian Association of Technical Norms (ABNT). The ABNT specify the protocols for the static and dynamic tests, using the same treatments as the greenhouse test (DMA $806^{\circledR}$ (SL) - $1005 \mathrm{~g}^{\text {a.e }} \mathrm{ha}^{-1}$ ), clethodim $\left(\right.$ Select $^{\circledR}$ (EC) - $192 \mathrm{~g}$ a.i ha $\left.{ }^{-1}\right)$, haloxyfopp-methyl (VerdictR ${ }^{\circledR}$ (EC) - $62.4 \mathrm{~g}$ a.i ha $^{-1}$ ), 2,4-D + clethodim $\left(1005+192 \mathrm{~g} \mathrm{ha}^{-1}\right)$ and, 2,4-D + haloxyfop $\left(1005+62.4 \mathrm{~g} \mathrm{ha}^{-1}\right)$. According to label recommendations, mineral oil $(0.5 \% \mathrm{v} / \mathrm{v})$ was added to the spray mix with ACCase inhibitor herbicides.

The static test was performed with a $250 \mathrm{~mL}$ graduated cylinder. Each one was filled with $150 \mathrm{~mL}$ of water ( $\mathrm{pH}$ 6.51) and then added to the other components of the spray mix by using the following sequence: $2,4-\mathrm{D}$, graminicides, and adjuvant, and completing with $100 \mathrm{~mL}$ of water. The cylinder was sealed, shaken ten times in a rotation of $180^{\circ}$ during two seconds intervals, and allowed to rest for $2 \mathrm{~h}$ to obtain a new dispersal. This process was realized at 6 and $24 \mathrm{~h}$. The visual assessments were collected before and after the cylinder shake at $0,2,6$, and $24 \mathrm{~h}$ after each mixture, assessing the spray mix's homogeneity/heterogeneity. The parameters observed were the presence $(+)$ or absence $(-)$ of oil separation, sediment formation, foam, lumps, flakes, and crystal formation.

The dynamic test was performed with $400 \mathrm{~mL}$ Beckers, following the same protocol used in the static test. After preparation, the Beckers were allocated into a shaker rack for two hours with a $150 \mathrm{rpm}$ shake speed and allowed to rest for ten minutes to conduct the same measurements as the statistical test.

\section{Statistical analysis}

The data collected from the visual assessments of control and shoot dry mass were submitted to the variance test ANOVA $(p \leq 0.05)$. The F significant data were then submitted to the LSD test with a $5 \%$ level of significance.

\section{RESULTS AND DISCUSSION}

There was no significant difference observed between herbicide treatment with and without inhibitor at 14 and 35 DAA (Figure 1A and B). Malathion acts as a synergist with some herbicides, inhibiting the metabolization process; thus, enabling herbicides to reach the enzymatic binding site.

Based on the results mentioned above, higher control of sourgrass was expected with graminicides mixed with 2,4-D and associated with malathion sprays; however, this behavior was not observed. This is likely due to the fact the CYP450 enzymes, which are inhibited by malathion, are not involved in the process that results in antagonism. It suggests that enzymes expressed to detoxify $2,4-\mathrm{D}$ in sourgrass were not inhibited by malathion in vivo. 


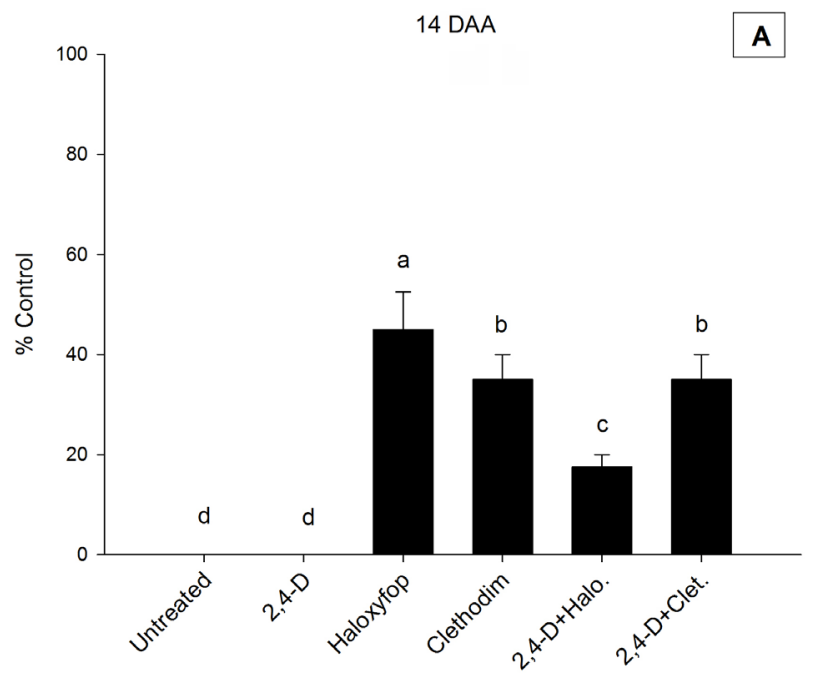

Treatments

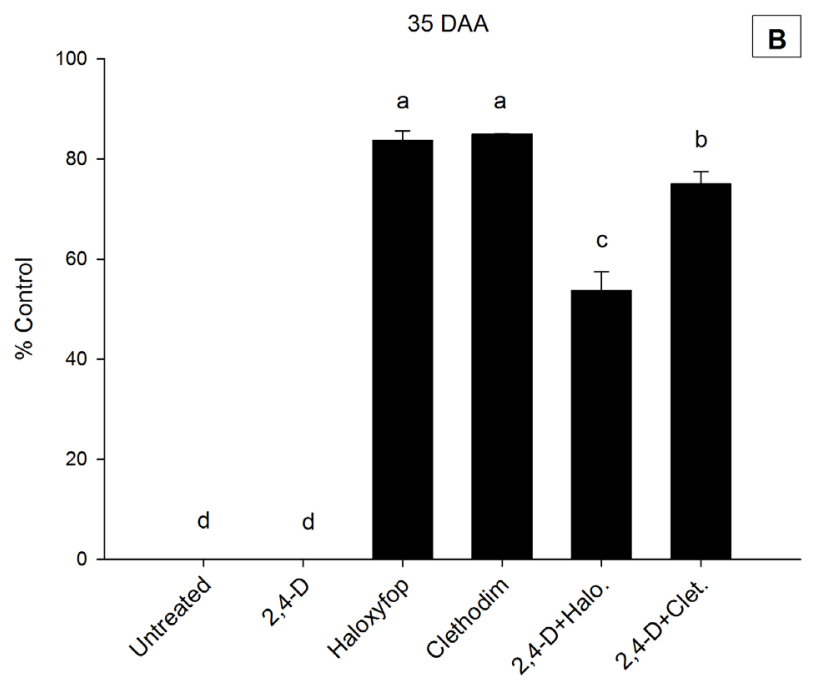

Treatments

Figure 1: Visual assessments of control at 14 DAA (A) and 35 DAA (B) of herbicides in flowering $D$. insularis plants. The small letter indicates significant differences by LSD test $(p \leq 0.05)$ between the treatments. Values represent the mean $\pm S D(n=8)$.

Han et al. (2013) reported that 2,4-D enhanced protection in Lolium rigidum against chlorsulfuron and diclofop-methyl action. In this case, malathion was able to reverse the 2,4-D protective effect on chlorsulfuron; however, the same effect was not observed on diclofopmethyl.

CYP450 is a group of enzymes with distinct gene expressions from different families participating in xenobiotic agents' metabolization (Werck-Reichhart; Hehn; Didierjean, 2000). The inhibition of an enzyme may not be sufficient to express the expected action of malathion on sourgrass.

Hidayat and Preston (2001) observed that the enzymes responsible for detoxifying fluazifop are different from those that detoxify imazethapyr in Digitaria sanguinalis. Preston et al. (1996) analyzed $L$. rigidum with multiple resistance and observed the action of different inhibitors, where the aminobenzotriazole (ABT) and piperonyl butoxide inhibited the simazine and chlorotoluron metabolization. On the one hand, ABT alone inhibited diclofop metabolization, whereas malathion inhibited chlorsulfuron.

Besides the CYP450 enzymes, other enzymatic groups engaged in the herbicide metabolization process, such as glycosyl-transferases (GT) and glutathione S-transferases, conjugate the molecules (Yu; Powles, 2014). These groups of enzymes have different inhibitors, and malathion does not affect them.
At 14 DAA (Figure 1A), chlorosis, purplish coloration, and apical meristem death were observed, which are characteristic graminicide symptoms in monocots (Barroso et al., 2010; Defelice et al., 1989). All these symptoms were visible in the plants submitted to isolated graminicide spray or a mixture with 2,4-D. This kind of symptom occurs due to the inhibition of the ACCase enzyme with no formation of malonyl-CoA, an intermediary compound of lipid formation which is essential for membrane structure and cell walls (Rodrigues; Almeida, 2011; Kukorelli; Reisinger; Pike, 2013).

There was a statistical difference between both graminicides in respect of the different symptom response time. At 14DAA, Haloxyfop had more pronounced symptoms (45\%) when compared with clethodim (35\%) (Figure 1A). Conversely, 2,4-D + haloxyfop achieved only $17.5 \%$ of control, suggesting an antagonistic effect in the mixture of these herbicides. Isolated clethodim and 2,4-D + clethodim (Figure 1) had the same percentage of control (35\%).

In the JIP test at 14 DAA (Figure 2A), an alteration of plant metabolism was observed. The only herbicide to present a behavior close to the control was 2,4-D. The treatments, including haloxyfop, 2,4-D + haloxyfop, clethodim, and 2,4-D + clethodim led to an increase of heat dissipation $\left(\mathrm{DI}_{0} / \mathrm{RC}\right)$ and a decrease of photochemical activity $\left(\mathrm{PI}_{\text {total }}\right.$ and $\mathrm{PI}_{\mathrm{ABS}}$ ) (Figure 2A). This kind of physiological response occurs due to ACCase inhibitors and causes indirect effects on photosynthesis, impacting the stability of thylakoid 
membranes; thus, affecting the photochemical stage (Kalaji et al., 2017). $\mathrm{DI}_{0} / \mathrm{RC}$ increase may be regarded as a response of the plants to avoid the excess energy accumulation in the reaction center $(\mathrm{RC})$ by inhibiting the reactive oxygen species (Szabó; Bergantino; Giacometti, 2005).

It is important to emphasize that the energy absorbed by chlorophyll can be used for the photochemical stage of photosynthesis, and the excess energy can be dissipated in the form of heat or re-emitted as fluorescence. These three processes compete against each other, and the responses are inversely proportional, where the increase of one decreases another (Maxwell; Johnson, 2000).

$\mathrm{DI} / \mathrm{RC}$ increase may also be linked to the apparent size of the antenna complex (ABS/RC) and trapping flux $\left(\mathrm{TR}_{0} / \mathrm{RC}\right)$, which suggests high energy captured by $\mathrm{RC}$ (Castro et al., 2011). However, this study shows that energy is not being used in the photochemical stage $\left(\mathrm{PI}_{\text {total }}\right.$ and $\mathrm{PI}_{\mathrm{ABS}}$ ) but is being dissipated in the form of heat (DI/RC).
According to Christen et al. (2007), the plants increase the antenna complex size to compensate for the loss in heat dissipation flux (DI/RC). Nevertheless, with the expansion of ABS/RC, more energy from sunlight is captured for the plants $\left(\mathrm{TR}_{0} / \mathrm{RC}\right)$, causing excess energy in reaction centers (Castro et al., 2011).

At 35 DAA (Figure 1B), plants subjected to clethodim treatment obtained a high control rate $(85 \%)$, in line with the studies of Gilo et al. (2016), who observed that clethodim controlled the same weed at a rate of $85 \%$. Haloxyfop presented a similar rate of $83.75 \%$ control (Figure 1B). This behavior was also reported by Barroso et al. (2010), where haloxyfop was efficient in controlling Brachiaria decumbens, Brachiaria plantaginea, Digitaria ciliares, Eleusine indica, and Cenchrus echinatus. In sourgrass plants, the control obtained with haloxyfop was $100 \%$, with dry mass reduced by $97 \%$ (Barroso; Albrecht; Reis, 2014; Leal et al., 2020).

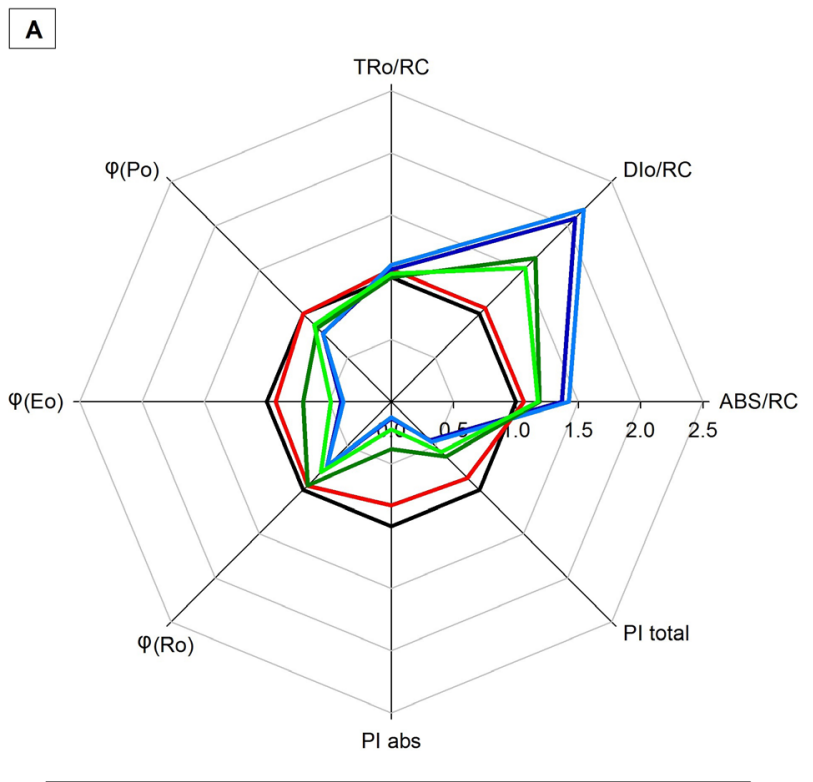

14 DAA

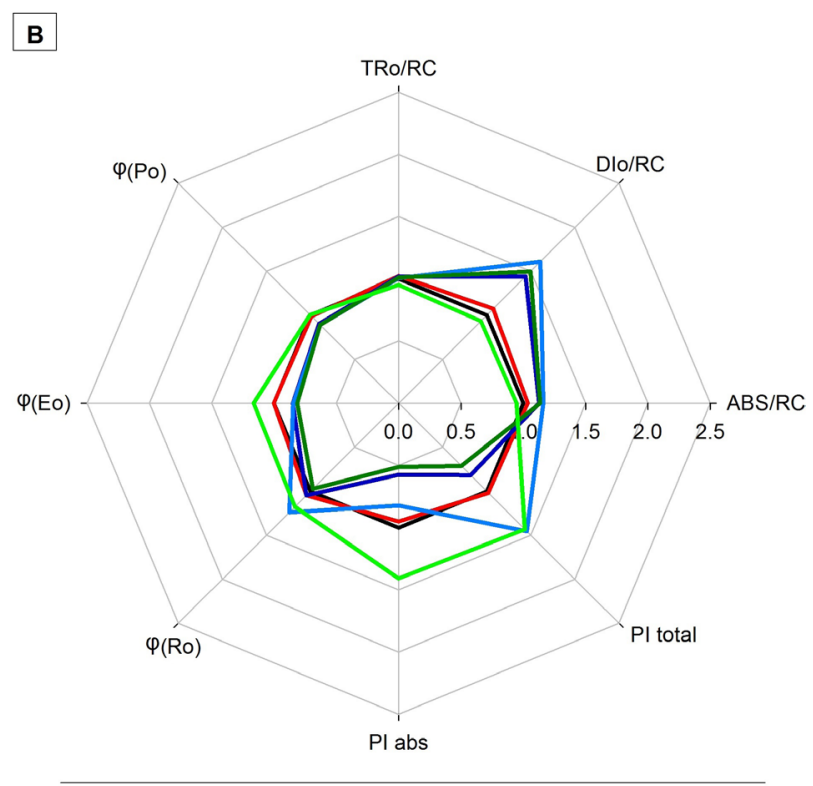

35 DAA
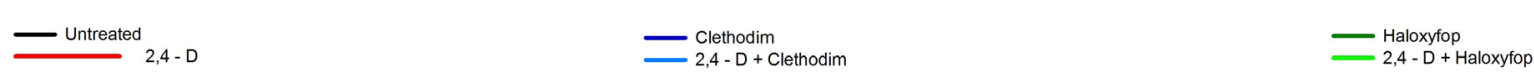

Figure 2: Chlorophyll a fluorescence transient in D. insularis plants at 14 (A) and 35 (B) days after the application (DAA) of herbicides haloxyfop, 2,4-D plus haloxyfop (A) and clethodim, 2,4-D plus clethodim. ABS/RC, absorption flux (of antenna chlorophyll) per reaction center (RC); $\varphi$ Ro, efficiency/probability with, which an electron from the intersystem electron carrier moves to reduce end electron acceptors at the PSI acceptor side (RE); DIO/RC, dissipation of an active RC); $\varphi$ Eo, quantum yield for electron transport (ET); $\varphi$ Po, maximum quantum yield for primary photochemistry; $\varphi$ Ro, quantum yield for reduction of end electron acceptors at the PSI acceptor side; PIABS, performance index (potential) for energy conservation from exciton to the reduction of intersystem electron acceptors; PItotal, performance index (potential) for energy conservation from exciton to the reduction of PSI end acceptors; TRO/RC, maximum trapping rate per RC. 
The isolated 2,4-D did not cause injuries in sourgrass (Figures 1 and 2) since monocots are tolerant of auxin herbicides. Some factors like reduced translocation by vascular anatomy and hydroxylation reactions of the molecule, which leads to a degradation in the plant (Peterson et al., 2016), could explain this effect. Although 2,4-D does not affect monocots, it is frequently mixed in the spray tank to control broadleaf weeds present in the same area.

When 2,4-D was mixed with haloxyfop, a reduction of the graminicide control (Figures 1 and 3 ) was observed. The difference between haloxyfop and 2,4-D + haloxyfop in visual assessments was higher by $30 \%$ (Figures 1B). An increase in dry shoot mass up to $39 \%$ (Figure 3) was observed compared with isolated haloxyfop. On the other hand, 2,4-D + clethodim reduced the visual control by $10 \%$ of isolated clethodim (Figure 1B) with shoot dry mass reduction of $18 \%$ approximately (Figure 3 ). These results show that the antagonism between $2,4-\mathrm{D}+$ clethodim was lower than 2,4-D + haloxyfop.

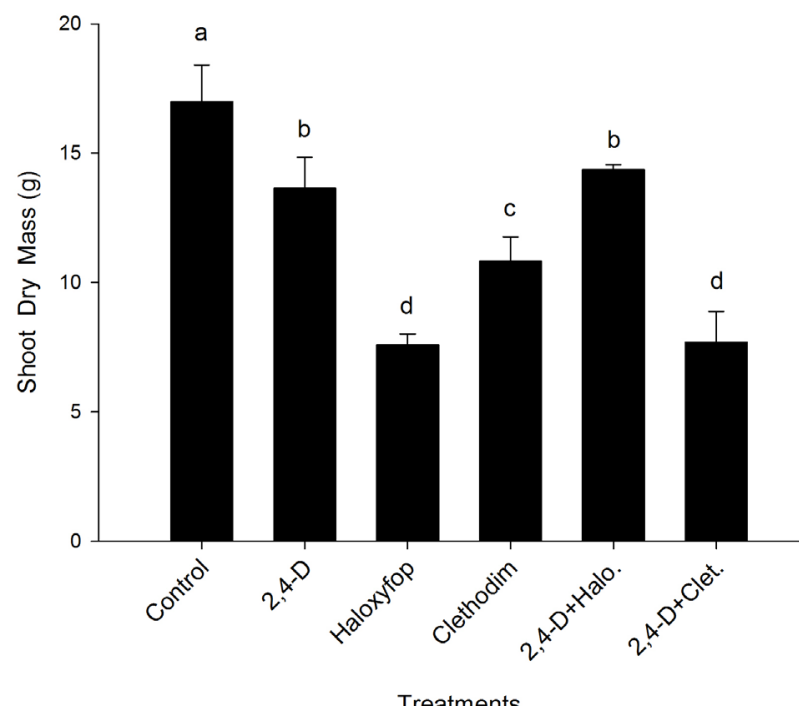

Figure 3: Shoot dry mass of $D$. insularis plants after collection at 35 DAA. The small letter indicates significant differences by LSD test $(p \leq 0.05)$ between the treatments. Values represent the mean $\pm S D(n=8)$.

Studies have helped understand the antagonism between graminicides and 2,4-D herbicides. Leal et al. (2020) evaluated the $D$. insularis control under treatment with 2,4-D associated with haloxyfop, observing a $40 \%$ difference between the mixture and isolated haloxyfop. The authors concluded there must be a difference of six days between the application of haloxyfop and 2,4$\mathrm{D}$ to control the flowering sourgrass; furthermore, the graminicide must be sprayed first in this case.

At 35 DAA (Figure 2B), haloxyfop and clethodim caused more damages to the photosynthetic apparatus than 2,4-D + haloxyfop. The latter inclined to recovery, with a reduction of DI/RC, whereas 2,4-D + clethodim (Figure 2B) continued with high heat dissipation and more damage, resulting in similar effects as that of isolated clethodim. Thus, 2,4-D + clethodim had a better performance in the control of sourgrass than 2,4-D + haloxyfop. Control may reduce by almost $50 \%$ from the moment the plant regrows, which hinders management in advance stages (Gazola et al., 2016; Procópio et al., 2006). The increase in regrowth rates and photosynthetic recovery is associated with increased dry mass in these plants (Figures 2B and 3).

These data are endorsed by Barnes and Oliver (2004), who mixed chloransulan with aryloxyphenoxypropionate or cyclohexanedine herbicides for the control of the annual weed, such as Sorghum halepense, Eleusine indica, Digitaria sanguinalis, Setaria glauca, and Echinochloa crus-galli, reporting that the mixture of chloransulan + sethoxydim presented better performance than chloransulan + fluazifop or quizalofop.

Moreover, all evaluations in static and dynamic tests showed the absence of lumps, flakes, and crystal formation in the compatibility test (Table 1). After preparing the spray-mix in the static test, the foam was found in all treatments with no chemical-phase separation (homogeneity) (Table 1).

After 2, 6, and $24 \mathrm{~h}$ of rest (Table 1), 2,4-D + clethodim showed oil-phase separation at 6 and $24 \mathrm{~h}$ and 2,4-D + haloxyfop at $24 \mathrm{~h}$; however, after shaking, all spray-mixes became homogeneous again. The dynamic test did not present sediment formation after $2 \mathrm{~h}$, but 2,4$\mathrm{D}+$ graminicides (clethodim and haloxyfop) presented oil-phase separation.

According to NBR 13875:2014 normative of the Brazilian Association of Technical Norms (ABNT), the results obtained in both tests showed that the isolated herbicides (+ adjuvants) were classified as homogeneous and compatible. On the other hand, 2,4-D + clethodim and 2,4-D + haloxyfop were classified as heterogeneous and incompatible. These results may be associated with reduced efficacy when 2,4-D is mixed with both graminicides in the tank.

The incompatibility identified in this study requires further examination since it may be related to the antagonistic effect observed between 2,4-D and graminicides, given that CYP450 enzymes inhibited by malathion are not involved in this antagonistic effect. 
Table 1: Compatibility test of spraying mix, evaluating homogeneity between herbicides (clethodim; haloxyfop; 2,4-D; 2,4-D + haloxyfop; and 2,4-D + clethodim) and adjuvant at 0, 2, 6, and $24 \mathrm{~h}$ before and after cylinder shake. The parameters observed were presence (+) or absence (-) of oil separation, sediment formation, foam, lumps, flakes, and crystal formation.

\begin{tabular}{|c|c|c|c|c|c|c|c|c|c|c|}
\hline \multirow{2}{*}{ Classification } & \multirow{2}{*}{ Treatment } & \multirow{2}{*}{$\mathrm{Oh}$} & \multicolumn{2}{|c|}{$2 \mathrm{~h}$} & \multicolumn{2}{|c|}{$6 \mathrm{~h}$} & \multicolumn{2}{|c|}{$24 \mathrm{~h}$} & \multicolumn{2}{|c|}{ Dinamic } \\
\hline & & & res $^{1}$ & $\mathrm{red}^{2}$ & rest & red & rest & red & Agit $^{3}$ & rest \\
\hline \multirow{6}{*}{ Homogeneity } & Adjuvant & + & + & + & + & + & + & + & + & + \\
\hline & Haloxyfop & + & + & + & + & + & + & + & + & + \\
\hline & Clethodim & + & + & + & + & + & + & + & + & + \\
\hline & $2,4-D$ & + & + & + & + & + & + & + & + & + \\
\hline & 2,4-D+Hal. & + & + & + & + & + & - & + & - & - \\
\hline & 2,4-D+Cle. & + & + & + & - & + & - & + & - & - \\
\hline
\end{tabular}

${ }^{1}$ Assessments after resting, ${ }^{2}$ redispertion of tank mixture and ${ }^{3}$ agitation.

\section{CONCLUSIONS}

Malathion did not show any improvement in controlling sourgrass when sprayed two hours before the herbicides 2,4-D + clethodim or haloxyfop in a tank mix, suggesting that CYP450 enzymes, inhibited by malathion, are not involved in the antagonistic effect, which occurs between 2,4-D and both graminicides (clethodim and haloxyfop) used in the management of sourgrass. The 2,4$\mathrm{D}+$ haloxyfop in tank mix demonstrated less efficiency in controlling sourgrass compared with 2,4-D + clethodim. Both mixtures, 2,4-D + haloxyfop or clethodim, are incompatible in a tank mix, which may be associated with reduced efficacy in sourgrass management. Further studies are required to clarify this issue.

\section{ACKNOWLEDGMENTS}

This study was financed in part by the Coordenação de Aperfeiçoamento de Pessoal de Nível Superior- Brasil (CAPES) - Finance Code 001.

\section{REFERENCES}

ASSOCIAÇÃO BRASILEIRA DE NORMAS TÉCNICAS - ABNT.

NBR 13875:2014. Agrotóxicos e afins - Avaliação de compatibilidade físico-química. Rio de Janeiro, 2014. 12p.

ARCAUTE, C. R.; SOLONESKI, S.; LARRAMENDY, M. L. Synergism of mixtures of dicamba and 2, 4-dichlorophenoxyacetic acid herbicide formulations on the neotropical fish Cnesterodon decemmaculatus (Pisces, Poeciliidae). Environmental Pollution, 236:33-39, 2018.

BARNES, J. W.; OLIVER, L. R. Cloransulam antagonizes annual grass control with aryloxyphenoxypropionate graminicides but not cyclohexanediones. Weed Technology, 18(3):763772, 2004.

BARROSO, A. L. L. et al. Eficácia de herbicidas inibidores da ACCase no controle de gramíneas em lavouras de soja. Planta Daninha, 28(1):149-157, 2010.

BARROSO, A. A. M.; ALBRECHT, A. J. P.; REIS, F. C. Interação entre herbicidas inibidores da accase e diferentes formulações de glyphosate no controle de capim-amargoso. Planta Daninha, 32(3):619-627, 2014.

CALABRESE, E. J. Toxicological consequences of multiple chemical interactions: A primer. Toxicology, 105(2-3):121135, 1995.

CASTRO, F. A. et al. Relationship between photochemical efficiency (IIP-Test Parameters) and portable chlorophyll meter readings in papaya plants. Brazilian Journal of Plant Physiology, 23(4):295-304, 2011.

CHRISTEN, D. et al. Characterization and early detection of grapevine (Vitis vinifera) stress responses to esca disease by in situ chlorophyll fluorescence and comparison with drought stress. Environmental and Experimental Botany, 60(3):504-514, 2007.

COLBY, S. R. Calculating synergistic and antagonistic responses of herbicide combinations. Weeds, 15(1):20-22, 1967.

DALAZEN G. et al. Occurrence and importance of herbicide resistance caused by degradation enhancement for weed management. Revista Brasileira de Herbicidas, 15(1): 26-38, 2016.

DALAZEN, G. et al. Degradation enhancement as the mechanism of resistance to imazethapyr in barnyardgrass. Planta Daninha, 36:e018179504, 2018. 
DAMALAS, C. A. Herbicide tank mixtures: Common interactions. International Journal of Agriculture and Biology, 6(1):209-212, 2004.

DEFELICE, M. S. et al. Weed control in soybeans (Glycine max) with reduced rates of postemergence herbicides. Weed Science, 37(3):365-374, 1989.

FRANS, R.; CROWLEY, H. Experimental design and techniques for measuring and analyzing plant responses to weed control practices. In: CAMPER, D. (Ed.). Research methods in weed science. 3. ed. Champaign: Southern Weed Science Society, p.29-45, 1986.

GAZOLA, T. et al. Características biológicas de Digitaria insularis que conferem sua resistência à herbicidas e opções de manejo. Científica, 44(4):557-567, 2016.

GAZZIERO, D. L. P. et al. Estimating yield losses in soybean due to sourgrass interference. Planta Daninha, 37:e019190835, 2019.

GEMELLI, A. et al. Aspectos da biologia de Digitaria insularis resistente ao glyphosate e implicações para o seu controle. Revista Brasileira de Herbicidas, 11(2):231240, 2012.

GILO, E. G. et al. Alternatives for chemical management of sourgrass. Bioscience Journal, 32(4):881-889, 2016.

HAN, H. et al. Enhanced herbicide metabolism induced by 2, 4-D in herbicide susceptible Lolium rigidum provides protection against diclofop-methyl. Pest Management Science, 69(9):996-1000, 2013.

HATZIOS, K. K.; PENNER, D. Interactions of herbicides with other agrochemicals in higher plants, Weed Science, 1:1-63, 1985.

HIDAYAT, I.; PRESTON, C. Cross-resistance to imazethapyr in a fluazifop-P-butyl-resistant population of Digitaria sanguinalis. Pesticide Biochemistry and Physiology, 71(3):190-195, 2001.

HIROSE, S. et al. Tissue-specific expression of rice CYP72A21 induced by auxins and herbicides. Plant Biotechnology Reports, 1(1):27-36, 2007.

KALAJI, H. M. et al. Frequently asked questions about chlorophyll fluorescence, the sequel. Photosynthesis Research, 132(1):13-66, 2017.

KISSMANN, K. G.; GROTH, D. Plantas infestantes e nocivas. 2. Ed. São Paulo: Basf Brasileira S. A. v. 1, 1997. 824p.

KREUZ, K.; TOMMASINI, R.; MARTINOIA, E. Old enzymes for a new job (herbicide detoxification in plants). Plant Physiology, 111(2):349, 1996.
KUKORELLI, G.; REISINGER, P.; PINKE, G. ACCase inhibitor herbicides-selectivity, weed resistance and fitness cost: A review. International journal of pest management, 59(3):165-173, 2013.

LEAL, J. F. L. et al. 2, 4-D and haloxyfop-P-methyl interaction: Sequential and interval applications to effectively control sourgrass (Digitaria insularis L.) and fleabane (Conyza spp. L.). Agronomy Journal, 112(2):1216-1226, 2020.

MACHADO, A. F. L. et al. Caracterização anatômica de folha, colmo e rizoma de Digitaria insularis. Planta Daninha, 26(1):1-8, 2008.

MAXWELL, K.; JOHNSON, G. N. Chlorophyll fluorescence A practical guide. Journal of experimental botany, 51(345):659-668, 2000.

OGLIARI, J. et al. Analysis of the electrophoretic profiles of cytoplasmic proteins to verify detoxification of the herbicide mesotrione in Zea mays plants. Planta Daninha, 32(1):161-172, 2014.

PETERSON, M. A. et al. 2, 4-D past, present, and future: A review. Weed Technology, 30(2): 303-345, 2016.

PRESTON, C. et al. Multiple resistance to dissimilar herbicide chemistries in a biotype of Lolium rigidum due to enhanced activity of several herbicide degrading enzymes. Pesticide Biochemistry and Physiology, 54(2):123-134, 1996.

PROCÓPIO, S. O. et al. Efeitos de dessecantes no controle de plantas daninhas na cultura da soja. Planta Daninha, 24(1):193-197, 2006.

RODRIGUES, B. N.; ALMEIDA, F. S. de. Guia de herbicidas. 6. ed. Londrina, PR: IAPAR, 2011. 764p.

STRASSER, R. J.; TSIMILLI-MICHAEL, M.; SRIVASTAVA, A. Analysis of the chlorophyll a fluorescence transient. In: PAPAGEORGIOU, G. C.; GOVINDJEE, G. (Eds.), Chlorophyll a fluorescence: A signature of photosynthesis. Dordrecht, The Netherlands: Springer, p.321-362, 2004.

SZABÓ, I.; BERGANTINO, E.; GIACOMETTI, G. M. Light and oxygenic photosynthesis: Energy dissipation as a protection mechanism against photo-oxidation. EMBO reports, 6(7): 629-634, 2005.

TAKANO, H. K. et al. Spread of glyphosate-resistant sourgrass (Digitaria insularis): Independent selections or merely propagule dissemination. Weed Biology and Management, 18(1):50-59, 2018. 
TSIMILLI-MICHAEL, M.; STRASSER, R. J. In vivo assessment of stress impact on plant's vitality: Applications in detecting and evaluating the beneficial role of mycorrhization on host plants. In: VARMA, A. (Ed.). Mycorrhiza. Berlin, Heidelberg: Springer mycorrhiza, p.679-703, 2008.

WERCK-REICHHART, D.; HEHN, A.; DIDIERJEAN, L. Cytochromes P450 for engineering herbicide tolerance. Trends in Plant Science, 5(3):116-123, 2000.
YU, Q.; POWLES, S. Metabolism-based herbicide resistance and cross-resistance in crop weeds: A threat to herbicide sustainability and global crop production. Plant Physiology, 166(3):1106-1118, 2014.

ZHANG, W. Fenoxaprop interactions for Barnyardgrass (Echinochloa crus-galli) control in rice. Weed technology, 19(2):293-297, 2005.

ZOBIOLE, L. H. S. et al. Controle de capim-amargoso perenizado em pleno florescimento. Revista Brasileira de Herbicidas, 15(2):157-164, 2016. 